This page intentionally left blank 


\section{ACCOUNTING/ FINANCE}

bESSONS OF

西

\section{ifangld Bifmall, Ir.}

Cornell University, USA

\section{A Case Study \\ NRON}

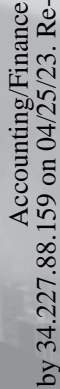




\section{Published by}

World Scientific Publishing Co. Pte. Ltd.

5 Toh Tuck Link, Singapore 596224

USA office: 27 Warren Street, Suite 401-402, Hackensack, NJ 07601

UK office: 57 Shelton Street, Covent Garden, London WC2H 9HE

\section{British Library Cataloguing-in-Publication Data}

A catalogue record for this book is available from the British Library.

\section{ACCOUNTING/FINANCE LESSONS OF ENRON A Case Study}

Copyright $@ 2008$ by World Scientific Publishing Co. Pte. Ltd.

All rights reserved. This book, or parts thereof, may not be reproduced in any form or by any means, electronic or mechanical, including photocopying, recording or any information storage and retrieval system now known or to be invented, without written permission from the Publisher.

For photocopying of material in this volume, please pay a copying fee through the Copyright Clearance Center, Inc., 222 Rosewood Drive, Danvers, MA 01923, USA. In this case permission to photocopy is not required from the publisher.

ISBN-13 978-981-279-030-9

ISBN-10 981-279-030-6

Typeset by Stallion Press

Email: enquiries@stallionpress.com

Printed in Singapore. 


\section{Contents}

Introduction vii

Acknowledgments $\quad$ ix

1 The Enron Success and Failure 1

2 Enron as of 31 December $2000 \quad 12$

3 First Six Months of 2001: Before the Storm 31

4 Sherron Watkins' Letter to Kenneth L. Lay 41

5 The Clouds Burst $\quad 51$

6 The 100-Year Flood 63

7 JEDI and Chewco: Not the Movie 69

$8 \quad$ LJM1 and Rhythms $\quad 85$

$9 \quad$ LJM2 and Raptors I and III 98

10 LJM2 and Raptors II and IV 115

11 Other Transactions 122 
12 The Collapse

13 The Indictment of Lay and Skilling

14 The Trial

15 A Slice of the Skilling-Lay Trial 167

16 The Skilling-Lay Trial: Fair or Foul? 174

17 Mark to Market Accounting: Feeding the Growth Requirement

18 Concluding Observations

Index 


\section{Introduction}

There is a major problem in writing this book. To tell the story fairly, a very large number of complexities must be explained. For example, Chapter 2 discusses Enron's Year 2000 Annual Report. It is difficult to study that report and conclude that the firm is heading toward collapse. On the other hand, it is not difficult to identify footnotes that are vague and incomplete (of course, the author also has the benefit of hindsight).

Why write a casebook describing and evaluating events about which there have been criminal trials and extensive hearings?

First, we should review what a manager or financial analyst should have known about Enron based on publicly available accounting information. Second, the Powers Report (William Powers was the Chairman of the Special Investigation Committee of the Enron Board of Directors) provides us with a good foundation for understanding the accounting and financial decisions that contributed to Enron's collapse. Third, the Skilling-Lay Trial enables us to determine the worst aspects of Enron's actions, and gives us a chance to evaluate the Government's conduct of that trial.

To determine whether or not the Skilling-Lay trial was fair, it is important that we understand why the seventh largest US Corporation collapsed in 2001. Why did a profitable corporation with an apparently strong balance sheet go from a firm with profitable growth 
prospects to a bankrupt shell in a matter of less than 8 weeks (from mid-October to mid-December 2001)?

Even after restarting the accounting incomes of 1997-2001 in October 2001, Enron made over \$2 billion of net income over that four-year period. The accounting results of operations do not, by themselves, lead to a forecast of financial insolvency.

I have tried to explain the accounting and financial complexities of Enron and the Skilling-Lay trial as clearly as I could. But unfortunately, considerable complexity and confusion still remain. You should ask yourself - to what extent the accounting and financial complexities were likely to have been understood by Enron's senior management, by financial analysts, and by the Skilling-Lay jury? Also, were Skilling and Lay given a fair trial? Should the objective of the US Attorneys be to gain convictions or to seek justice? Does it matter to the society how a conviction is obtained?

One obvious conclusion to most readers would be that there should have been more effective limits placed on the complexity and opaqueness of the financial transactions and the accounting reports by Enron's top management. It would seem that by 1997, few if any managers or members of the Board of Directors at Enron truly and fully understood the financial transactions and the accounting implications as well as the legal aspects of those transactions. There should have been better accounting disclosures, but equally important Enron management should have made better financial decisions.

I hope this book will enlighten a wide range of readers including those who are not accounting-finance experts. It is also designed to be used in either an advanced accounting or finance college course as a supplement or the core component of a course. Enron supplies many useful lessons. The collapse need not have happened.

Harold Bierman, Jr. Cornell University Ithaca, New York 


\section{Acknowledgments}

My friends and colleagues, Ed. Altman, Dick Conway, Bob Frank, Jerry Hass, and Sy Smidt read early drafts and parts of this manuscript and rectified many errors.

Don Schnedeker, head librarian of the Johnson School supplied ready and cheerful assistance.

Barb Drake cheerfully typed many drafts.

Thanks to all of them mentioned above and many others. 